\title{
Myrtle Lake: a late- and post-glacial pollen diagram from northern Minnesota ${ }^{1}$
}

\author{
C. R. JANSSEN \\ Botanical Museum and Herbarium, Utrecht, Netherlands, \\ and \\ Limnological Research Center, University of Minnesota, Minneapolis, Minnesota \\ Received February 5, 1968
}

\begin{abstract}
A pollen diagram from a lake in the former bed of the eastern arm of Lake Agassiz in northern Minnesota records a vegetation of spruce forest followed by immigration successively of Pinus banksiana and (or) P. resinosa at 10000 B.P., then Abies and Pteridium, and still later Alnus. Between 8000 and 7000 B.P. prairie and (or) Quercus savanna prevailed on the uplands, followed by deciduous forests of mainly Quercus, Ostrya virginiana, Fraxinus pennsylvanica, and possibly Populus sp.

Slightly later, Pinus strobus migrated into the area, resulting in a gradual decline of pollen of deciduous forest types. Betula pollen, however, rises, and there is an indication of a return to prairie conditions prior to 3000 B.P.

During the 8000-7000 B.P. dry interval the lowland vegetation consisted of fens of Typha latifolia, Dryopteris thelypteris, and Cyperaceae. Later paludification and lateral expansion of the peatland gave rise to rather rich swamps of Picea mariana, Larix laricina, Alnus rugosa, and Thuja occidentalis. There are some conspicuous peaks of Myrica in the pollen diagram.

The time after 3000 B.P. is characterized by much Pinus strobus pollen and minima of deciduous trees and herbs. In the lowlands, formation of raised bogs and poor swamps and fens began, indicating a shift in climate towards wetter conditions. The arrival of white man in the area is reflected by the rise of $A m$ brosia. The shifts in overall peatland types are clearly accompanied by changes in the species composition of Pediastrum in Myrtle Lake, indicating corresponding changes in the lake waters.
\end{abstract}

Canadian Journal of Botany, 46, 1397 (1968)

\section{Introduction}

The waning of the Mankato ice sheet in lateWisconsin time left in its wake the large proglacial Lake Agassiz, which occupied large areas in northwestern and northern Minnesota and adjacent Canada. In Minnesota this lake came into existence about 12000 years ago when the Des Moines lobe and its St. Louis sublobe (of the Alborn phase of Wright and Ruhe 1965) retreated from the Red River and Red Lake lowlands. This lake, Lake Agassiz I, is marked along its southern and eastern rim by the Herman beach (Fig. 1). After a low-level stage resulting from the opening of an outlet to the east in Ontario, Lake Agassiz II (Campbell beach) arose about $10000-10500$ B.P., when the ice readvanced and closed the eastern outlet (Zoltai 1961). At this time the lake did not reach to the Red Lake lowland. About 9200 B.P. the final retreat of the ice began, and the lake withdrew from the Campbell beach, leaving the lake bed open for vegetational colonization.

Because of a strong climatic gradient to the west in northwestern Minnesota (McAndrews

${ }^{1}$ Contribution No. 54, Limnological Research Center, University of Minnesota; Mededelingen van het Botanisch Museum en Herbarium van de Riiksuniversitet te Utrecht No 282814
1966), as well as different soil types, the recent vegetation in the Lake Agassiz area varies greatly. The western part of the basin has clay soils covered by prairie and aspen parkland. In the eastern part patterned peatlands are interrupted by sandy beaches covered by upland vegetation (Heinselman 1963). The peatlands consist of fens, raised bogs, string bogs, swamps, and spruce islands arranged in an intricate pattern determined by surficial drainage.

Much of Minnesota is situated in the tension zone between prairie and deciduous forest. Towards the north this deciduous forest belt thins out and is replaced by aspen parkland (Fig. 1). Pollen studies in Minnesota (Wright et al. 1963; McAndrews 1966) point toward an eastern extension of the prairie formation in mid-postglacial time, followed by return of the forest. In the Itasca area of northwestern Minnesota the bogs began their development after this prairie period (Janssen 1967a). A C-14 date from the base of Lindford bog, west of the Myrtle Lake peatland, revealed an age of 4360 B.P. (Heinselman 1963), indicating that most of the peat accumulated after the prairie period. Since then, according to Heinselman, most of the vast peatlands of the Red Lake lowlands resulted from paludification rather than lake 


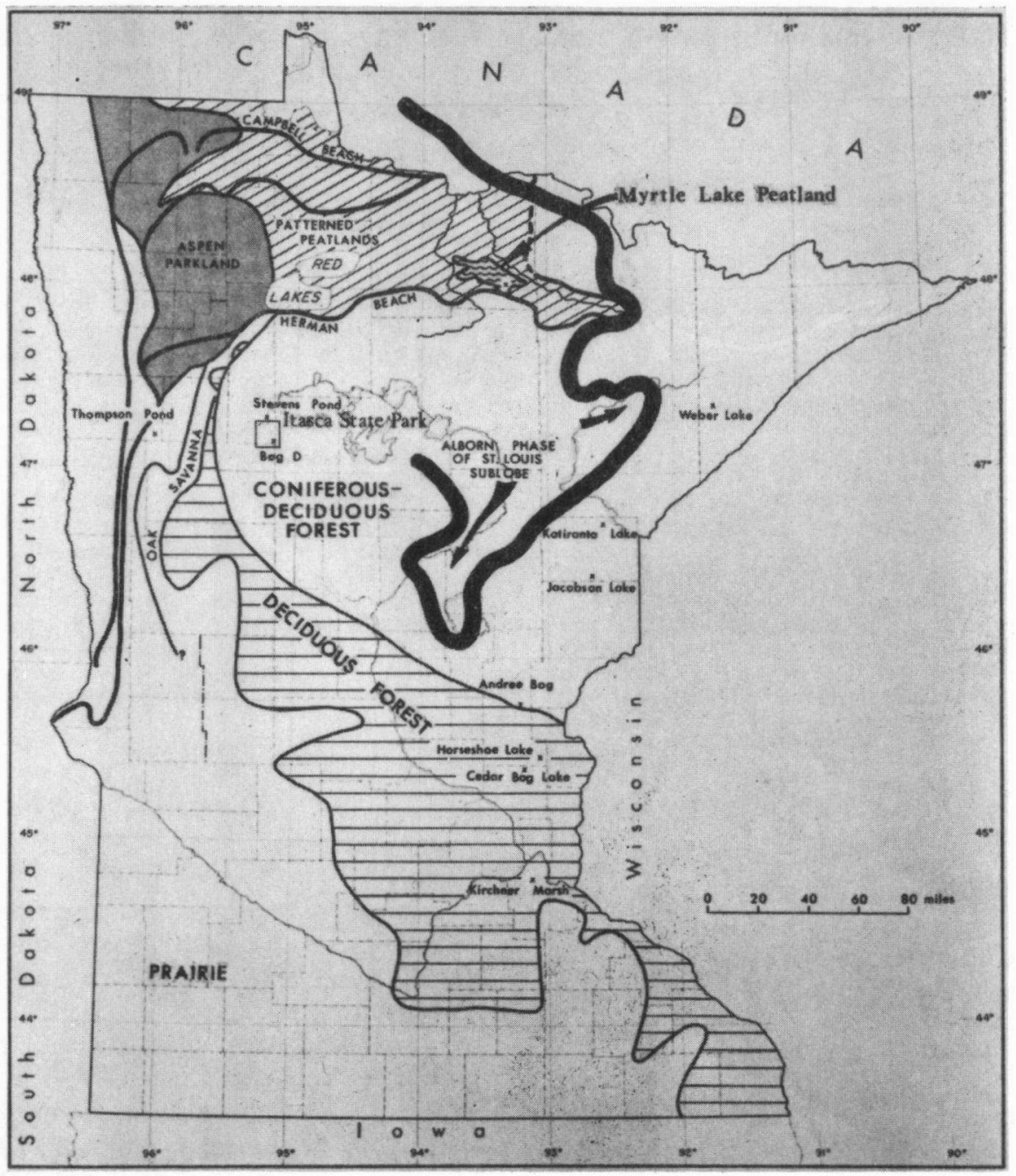

FIo. 1. Map of Minnesota showing the border of the latest recorded ice lobe in the area, beaches of southeastern Lake Agassiz, major recent vegetation types, and pollen sites mentioned in the text. Modified after Leverett (1932). McAndrews (1966), Schoenike (1963), and Wright and Ruhe (1965).

filling, especially along the margin. The question remains, however, what kind of vegetation occupied the area before peat accumulation started on a large scale?

The present work is part of an investigation on the development of these peatlands since the withdrawal of Lake Agassiz. Before detailed work can be undertaken on peat cores, the regional vegetational history of the area must be determined from pollen analysis of a lake sediment. One of the few lakes in the peatland is Myrtle Lake, 40 miles east of Red Lake and close to the eastern margin of the Lake Agassiz basin. A pollen diagram from this lake is presented in this paper.

\section{Myrtle Lake Peatland}

The Myrtle Lake peatland is situated on the water divide between the Little Fork and Big Fork Rivers (Fig. 2). Most of the vegetation types of the entire Lake Agassiz peatland are found there. The peat started to accumulate on a gentle slope to the north (Heinselman 1968). According to Heinselman (1963, 1968), the basal sedge peat is typically overlain by forest peat, and then by either Sphagnum peat or 


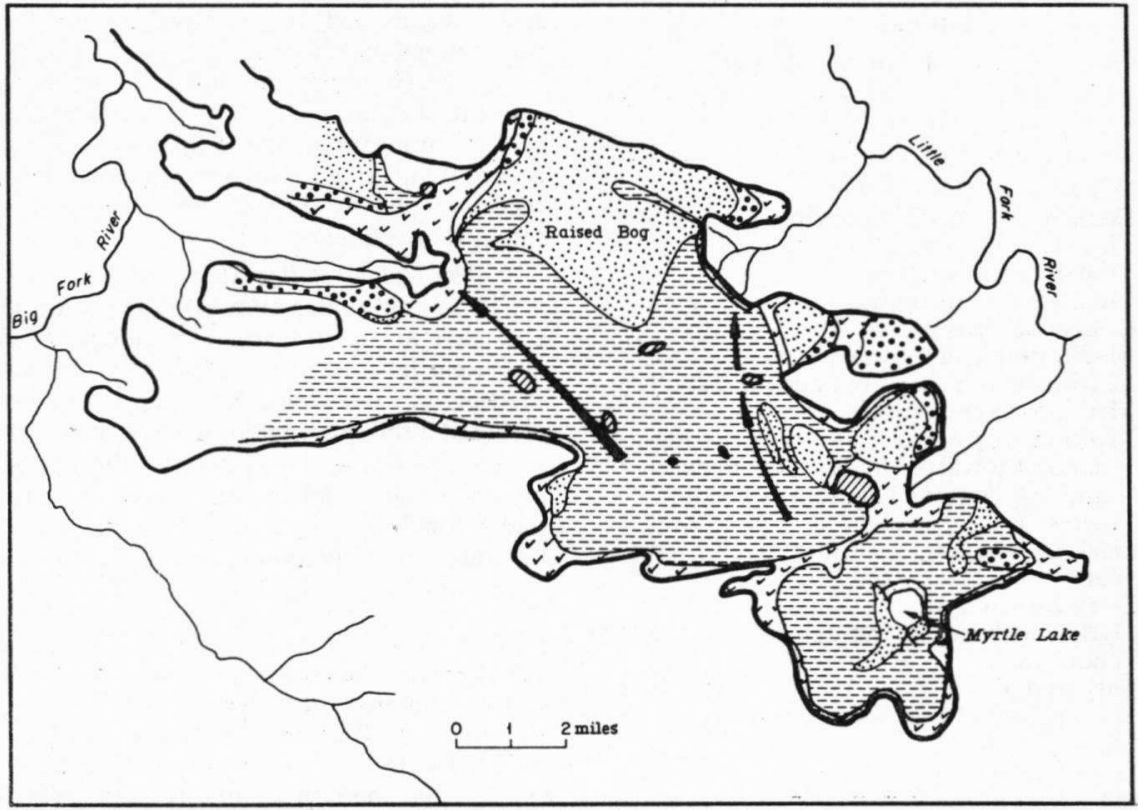

LEGEND

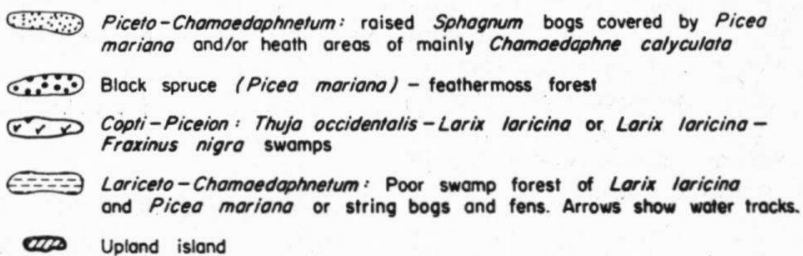

Fig. 2. Simplified vegetation map of the Myrtle Lake peatland. Modified after Heinselman (1968). For explanation see text.

mixed Sphagnum and sedge peat, but along the margin the sequence locally starts with forest peat, and in the center the forest layer is locally absent (Fig. 3A).

Myrtle Lake is situated 1.5 miles from the southern end of the peatland (Fig. 3B). It forms a deep pit in the substratum, and therefore its sediments should record the regional vegetation history before the peatland developed. The lake measures about a half mile across and is surrounded on all sides by peatland. At the southern end a remnant of an inflowing stream is found, almost obliterated by peat growth. The stratigraphy of the lake sediment is listed in Table I.

The vegetation types described by Heinselman $(1963,1968)$ for the area may be grouped (Fig. 2) according to a classification developed for the Itasca State Park area, 100 miles to the southwest (Janssen 1967b). Thus the poor swamp forest described by Heinselman, and probably the cedar string bog and fens, belong floristically to the Lariceto-Chamaedaphnetum (Janssen 1967b). The Sphagnum - black spruce - leatherleaf bog forest and Sphagnum-leatherleafKalmia-spruce heath, both of which are topographically raised (Heinselman 1968), are represented by the Piceto-Chamaedaphnetum. The rich swamp forest of Heinselman is the CoptiPiceion, or the unit labeled "transition" by Janssen (1967b). Most of the rich swamp forest is found along the margin of the peatland, but one rich Thuja occidentalis stand occurs along the northern margin of the lake. It gradually grades to poorer vegetation types toward the north. Along the other sides of the lake only poor swamp forest occurs.

\section{Methods}

Sampling and Processing

The Myrtle Lake core was taken through the frozen 
TABLE I

Sediment stratigraphy of Myrtle Lake

\begin{tabular}{cl}
\hline \multicolumn{1}{c}{ cm } & \multicolumn{1}{c}{ Strata } \\
\hline $0-145$ & Water \\
$145-440$ & Dark-brown medium-detritus gyttja \\
$440-505$ & Fine-detritus gyttja \\
$505-525$ & Coarse-detritus gyttja \\
$525-570$ & Medium-detritus gyttja \\
$570-595$ & Coarse-detritus gyttja \\
$595-695$ & Medium-detritus gyttja \\
$695-725$ & Detritus gyttja, slightly finer than above \\
$725-735$ & Medium-detritus gyttja \\
$735-825$ & Medium-detritus gyttja with increasing marl \\
& content towards the bottom; between 795 \\
& and 800 cm, marl content is small \\
$825-852$ & Marl with some snails \\
$852-863$ & Dark-brown gyttja, without much marl \\
$863-867$ & Marl \\
$867-875$ & Dark-brown gyttja \\
$875-895$ & Gyttja, with increasing detritus towards the \\
& bottom \\
$895-905$ & Silty gyttja \\
$905-925$ & Silt with wood and some snails \\
$925-975$ & Silt with wood \\
$975-1000$ & Grey-blue clay \\
\hline
\end{tabular}

surface of the lake by a modified 2-in. Livingstone sampler (Cushing and Wright 1965). Treatment of the core samples included boiling with $10 \% \mathrm{KOH}$ for 1 minute, sieving the mixture through a fine screen, addition of $10 \% \mathrm{HC} 1$, and acetolysis at $95{ }^{\circ} \mathrm{C}$ for 10 minutes. For microscopic investigation the material was mounted in silicone oil $(2000 \times$ csk $)$, without stain.

\section{Pollen Diagram}

The pollen diagram (Fig. 4) is divided in two parts, one showing the pollen types included in the upland pollen sum, the other those that were left outside the upland pollen sum. Within certain ecological-physiognomic groups the pollen curves have been arranged stratigraphically to show the greatest coincidence of occurrences and to visualize the successional trends.

The pollen numbers are calculated on the basis of two pollen sums (Janssen 1966).

\section{The Regional Pollen Sum}

The sediment type is lake sediment throughout. Many pollen types show regional values in the pollen diagram because of the large size of the lake and the peatland. This, of course, applies mostly for upland pollen types originating from species that, for most of the postglacial period, cannot have occurred on the shores of the lake. This is recognizable in the trend of the curves at many places in the diagram but especially the spectra above and below spectrum No. 60, where Picea, Betula, Pinus, and Quercus show exactly the percentages that are expected on the basis of spectrum No. 60 only.

Excluded from the regional pollen sum are pollen types from taxa that at any time might have grown in the lake itself and thus might show local values: Poaceae (Zizania), Cyperaceae (Scirpus), open-water types, and ecologically indeterminate types. The algae are also excluded. The black curves and the lined curves (with scale exaggerated $10 \times$ ) show percentages based upon this regional pollen sum.

All the types thus excluded from the regional pollen sum are shown on the right side of the diagram. An exception, however, is made for the Poaceae curve, which is almost identical with that of upland herbs and may therefore mostly record upland species of Poaceae, rather than Zizania.

\section{The Upland Pollen Sum}

The upland pollen sum is made up of the pollen types that have an upland origin. Excluded are the types that also were left out of the regional pollen sum, as well as the bog and fen types. An exception is Betula, which is included although it might have occurred in the bog as $B$. pumila. Percentages based upon the upland pollen sum are shown as supplemental curves (without exaggerated scale) for Ulmus, Quercus, Pinus, and the total of the upland herbs (including prairie herbs, Pteridium, and Sarcobatus).

\section{Identifications}

Identifications of pollen grains were made with the aid of the reference collection of recent pollen grains of the Limnological Research Center. Most of the pollen identifications follow the criteria of Faegri and Iversen (1964), Cushing (1963), and Janssen (1967a). The identification of Pediastrum species follows Prescott (1951).

Copies of the pollen counts are available at the Limnological Research Center, University of Minnesota.

\section{Pollen Analysis GENERAL}

To provide a useful scheme to discuss parts of the pollen sequence, the pollen diagram has been divided into zones that to a great extent are traceable at Weber, Jacobson, and Kotiranta lakes (Wright et al. 1968). The regional vegetation development can thus be compared with that elsewhere in northeastern Minnesota, as well as in other parts of Minnesota.

As the discussion of results will show, similar migration rates of forest dominants may result in similar pollen assemblages that are not necessarily synchronous everywhere. To avoid any time-stratigraphic implication for the zone boundaries, the convention of designating pollen zones by the initials of the site is followed here (Cushing 1967). The list below shows these indices and their literature references.
Weber Lake
Kortiranta Lake
WL Fries 1962
Jacobson Lake
KL Wright et al. 1968 (S. Jelgersma)
Bog D
JL Wright et al. 1968
(W. A. Watts)
Thompson Pond
BD McAndrews 1966
TP McAndrews 1966 


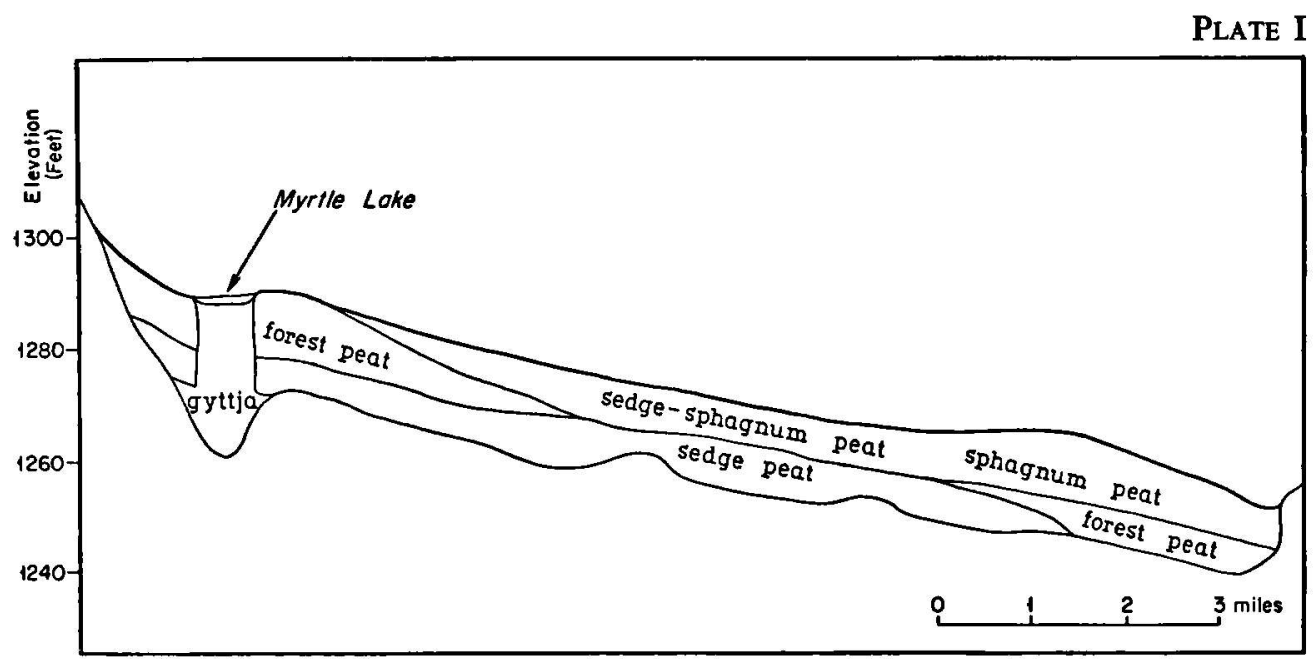

Fig. 3A. Cross section through the Myrtle Lake peatland, showing the main stratigraphic features. After Heinselman, 1963.

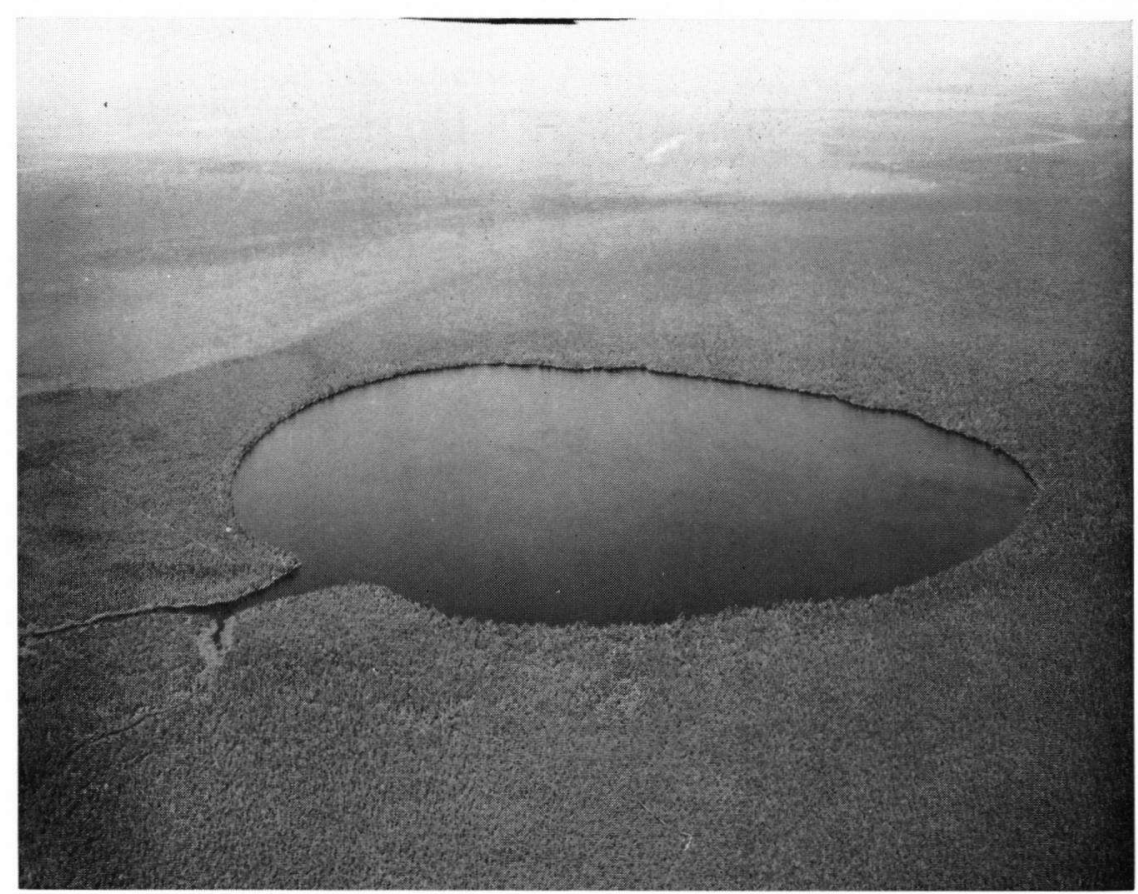

FIG. 3B. Aerial view of Myrtle Lake, looking northwest. Patterned fen is light area in background. 
Andree Bog

Cedar Bog Lake

AB Cushing 1964

CBL Cushing 1963

HL Cushing 1967

Horseshoe Lake

Kirchner Marsh

$$
\text { C. Winter) }
$$

The locations of these sites in relation to the major recent vegetation formations in Minnesota is shown in Fig. 1.

In the following sections, the regional features will be discussed for each pollen zone, together with interpretation of the development of the Myrtle Lake peatlands. The correlation of regional features with those elsewhere in the state is based on available C-14 dates. Table II shows the synchroneity for a number of sites and may be used throughout the discussion.

\section{ZONE ML-1}

Zone ML-1 is characterized by high values of Picea, low values of Pinus, and moderate values of Quercus, Artemisia, Larix, Chenopodiaceae, Poaceae, and Cyperaceae. Although Cyperaceae and Artemisia values are slightly higher than in the following zone, they are still too low to indicate a treeless vegetation of the type indicated by the basal sediments at Weber and Kotiranta Lakes (zones WL-1 $a$ and KL-1 $a$ ). Also the values of Larix and Picea are too high. A C-14 date from the base of the silt layer is $11120 \pm$ 210 B.P. (Y-1782), younger than the zone $1 a / 1 b$ transition at Kotiranta Lake. It therefore seems reasonable to assume that, at Myrtle Lake, zone $1 a$ is lacking. During that time pollen-free lake clays were deposited. The stratigraphic shift from clay to silt may reflect a withdrawal of Lake Agassiz I from the Herman beach, an event that occurred in northwestern Minnesota before 11740 B.P. (Y-1327; Shay 1965). Withdrawal of Lake Agassiz resulted in erosion from the area immediately south of Myrtle Lake, possibly by the now largely obliterated stream at the south end of the lake. In the pollen diagram the erosion is indicated by redeposited Cretaceous pollen grains at the base of the zone.

The local vegetation of ML-1 shows a striking parallel with that of JL-1, for Ranunculaceae, Myriophyllum, and Sparganium are present at both sites. Possibly also Equisetum and Lemna, abundant at Myrtle Lake, belong to this group of pioneer aquatics, as they have been called by Watts (1967). Pediastrum simplex is confined to

zone 1. According to information from P. J. Schroevers, it is a polysaprobic species; its presence is consistent with the sediment type. Also present is Pediastrum boryanum, but this species is almost ubiquitous.

Except for Quercus, Ulmus, and Ostrya-type pollen, which are found in late-glacial sediments at all sites in Minnesota, ML-1 has no pollen of other thermophilous trees. Typha latifolia, a temperate species now found in Scandinavia only south of the $14{ }^{\circ} \mathrm{C}$ July isotherm (Iversen 1954), is absent from the late-glacial at Myrtle, Weber, Jacobson, and Kotiranta lakes. At some sites in and north of the Anoka sand plain are single occurrences of this pollen type, probably a result of long-distance transport. At Andree Bog, Cedar Bog Lake, and Kirchner Marsh it is consistently present, and at Kirchner Marsh the presence of the plant itself is confirmed by macrofossils (Watts and Winter 1966). Nuphar, another thermophilous aquatic species (Iversen 1954), is also absent in zone $1 b$ at Myrtle, Weber, and Kotiranta lakes, but it is present to the south. In contrast to Typha, long-distance transport cannot account for single occurrences of Nuphar, which has a short dispersal distance. The occurrences of pollen of these aquatic types, as well as of thermophilous deciduous trees and of Abies and Pteridium, all imply a vegetational break at that time in the region near the present southern boundary of coniferous forests. Apparently this area constituted a (climatic?) boundary in the late-glacial as it does today. It is also the area where Wright et al. (1968) postulated the northern tree line of Picea during the time of zone $1 a$.

\section{ZONE ML-2}

At the transition from zone 1 to zone 2 there is a sharp increase of Ulmus and Pinus banksianal resinosa type. Quercus and Ostrya type also increase, and now-exotic deciduous tree types occur regularly. Picea decreases gradually to a small percentage, Pediastrum simplex disappears, Equisetum and Ranunculus type decline, and Nuphar has a short maximum just above the transition; these trends point to improving climatic conditions as well as quieter lake water, which is indicated also by a change in sediment to pure organic matter. The occurrence of these vascular species and the disappearance of Pediastrum simplex, which is the most planktonic 
of all the Pediastrum species, may also mean falling water levels.

A C-14 date at $890-895 \mathrm{~cm}$ places this transition at $10150 \pm 160$ B.P. (Y-1781), an age that is consistent with most of the hitherto-dated rises in pine throughout the state (Table II). The synchroneity of this feature over such a large area is striking. It is perfectly possible that pine trees did not arrive at the same time everywhere in northern Minnesota. If this is the case, then the pine pollen so easily dispersed over a great distance clearly overshadows the locally produced pollen, resulting in the sharp rise in the pine pollen curve. Preliminary pollen counts of a transition from sandy gyttja to pure gyttja in a core from the raised bog in the northern part of the Myrtle Lake peatland, dated at $10310 \pm 260$ B.P. (GX-0498; Heinselman 1968), also shows the pine rise at this level.

Zone ML-2 may be divided into zones $2 a$ and $2 b$. Zone $2 a$ has maxima of several deciduous elements: Ulmus, Quercus, Corylus, and Ostrya type. In zone $2 b$ are maxima of Pinus, Pteridium, and $A b i e s$ and an increase of Ambrosia. Throughout zone 2 Picea decreases, but most of the decline occurs in zone $2 a$. The Larix percentages remain relatively stable after a fall at the transition from zones 1 to 2 .

A similar zone 2 with higher values of mesic forest elements also is present at Weber Lake, but it is absent at most other eastern Minnesota sites. In most of the Itasca sites in northwestern Minnesota the lower pine period is too short, but at Stevens Pond a division on the same basis exists.

The order of the rise and maxima of Betula, Alnus, and Abies follows the migration pattern described by Wright et al. (1968). According to them these elements came from the south and appear progressively later towards the north. Abies first appears at KM, CBL, and $\mathrm{HL}$ before the pine rise: at $\mathrm{AB}, \mathrm{JL}$, and $\mathrm{WL}$ they come with the pine rise; and at Myrtle Lake they decidedly postdate the pine rise. There is also a shift in the relative position of the Abies maximum. In the south it is about at the pine rise or earlier, but at $\mathrm{JL}, \mathrm{WL}$, and $\mathrm{ML}$ it comes later.

Alnus follows the same pattern, but its maximum is delayed with respect to Abies. At KM, CBL, HL, and AB the rise of Alnus is found before the appearance of Abies. The differences in the Alnus maximum are even greater. At JL and WL it is in zone $2 b$, but at Myrtle Lake it comes in the next zone. The Betula maximum is the level where it might be expected: at the end of zone ML-2 $b$, thus intermediate between its position at Jacobson Lake and Weber Lake.

Another species that may belong to this southern migratory group is Pteridium. It appears at KM even before Abies; towards the north in the Anoka sand plain it appears at the same time as Abies and Pinus, giving rise to Cushing's Pinus-Pteridium assemblage zone. At JL and ML it is later: it appears there with the Alnus and Abies rise. At Weber Lake, finally, a Pteridium zone seems to be absent.

In the Myrtle Lake diagram there is little indication of the character and composition of the lowland vegetation. Pollen grains of Typha latifolia are present, but their percentages remain low. Actually the only pollen types that may have come from the lowland are Sphagnum, Picea, and Larix. In boreal regions Picea mariana and Larix laricina occur on uplands as well as in swamps (Raup 1935; Ritchie 1957; Thieret 1964). According to Heinselman (1963), the oldest peats in the Lake Agassiz area are sedge peats rather than forest peats. In the pollen diagram, however, there is no pollen assemblage that would point to a widespread occurrence of fens. Another possibility is that the area covered by lowland vegetation was smaller than it is now; much of the area might have been covered by upland and floodplain vegetation on the exposed clays of Lake Agassiz, and that it was not paludified until later (Heinselman 1963).

Although in boreal America similar forest types grow on all sorts of soil, Pinus banksiana tends to grow on sandy soils (beaches) or is a fire climax on other soil types. On richer soils Picea glauca, Populus balsamifera, and Populus tremuloides are common, the first two especially on floodplains (Raup 1935; Ritchie 1957) such as may have occurred over wide areas of the former lake bed. In all these forest types Shepherdia occurs in boreal America, but not Abies and Pteridium. In a sense the present difference between the boreal Picea forest and the temperate pine forest is the same as the difference between zones $2 a$ and $2 b$ in northern Minnesota, and between zones 1 and 2 toward southern Minnesota. The explanation may lie in the comigration of at least the dominant trees of forest communities. 
It remains questionable to what extent mesic deciduous elements were present or to what extent their pollen was contributed by longdistance transport. Pollen of Ulmus and Fraxinus is very abundant at Myrtle Lake. Wood of these trees has been found at the western edge of Lake Agassiz in the Assiniboine valley (Löve 1959). Therefore it seems likely that these trees were part of the regional vegetation at Myrtle Lake. They may have occurred with Picea, Abies, and Populus on the floodplains.

\section{ZONE ML-3}

\section{Regional Features}

Zone ML-3 is characterized by high pollen values of upland herbs, which suggest more open vegetation, and by high values of deciduous trees and low values of coniferous elements. The zone may be divided in three subzones.

In zone $3 a$ Quercus, Ambrosia, Artemisia, Poaceae, Typha latifolia, and Salix show values that are maximal for the entire diagram. Fraxinus pennsylvanica and Corylus increase, and Picea, Larix, and Pinus reach minimal percentages at the top of the subzone. There is a slight increase of Pinus strobus type.

At the base of zone $3 b$ Ostrya type rises abruptly. Pinus reaches a maximum at the top of the zone; it is almost entirely Pinus strobus type. Picea and Larix remain low, Quercus decreases, and Tilia makes its first appearance.

In zone $3 c$ Picea and Larix start to increase, but there is a new minimum of Pinus, together with a slight rise of the Pinus banksiana/resinosa type. Upland herbs reach a new maximum.

A few arguments may be made to include zone $3 c$ in zone 4 instead of in zone 3 because, as at $\mathrm{JL}, \mathrm{WL}$, and $\mathrm{KL}$, there is, from the base of zone $3 c$, a rise of Abies, Picea, and Larix. The counterarguments, which are more persuasive, include the following ones.

1. At JL a slight rise of Pinus banksiana/resinosa type clearly is shown at the upper part of zone 3.

2. At JL, WL, and KL Quercus, Ulmus, and Ostrya type have completed their decrease at the base of zone 4. This is not so in zone $3 c$ at Myrtle Lake.

3. There is still a maximum of upland herbs at Myrtle Lake.

4. Alnus shows low values in zone 4 at JL, WL, and KL. At Myrtle Lake Alnus shows a maximum.

\section{Zone $M L-3 a$}

Zone $3 a$ may be considered to represent the period with the greatest impact of the midpostglacial prairie period. A peak of Myriophyllum and Lemna may indicate a low water level for Myrtle Lake. Also, the abundant Typha latifolia and, at the base of the zone, a sharp peak of the Poaceae (Zizania type) are features that likewise may be connected with low water levels. A distinct maximum of upland herbs and deciduosu trees implies a climatic cause.

A C-14 date at the base of the zone is $7850 \pm$ 120 B.P. (Y-1780). This is synchronous with Cushing's low-water stage at Cedar Bog Lake $(7880 \pm 120, Y-1197)$ in his Dryopteris subzone. At Jacobson Lake zone $3 a$ is very thin, but at the transition of JL-2 and JL-3 there is a Quercus and herb maximum dated at $7210 \pm 80$ B.P. (Y-1690). This date is later than the Myrtle Lake date, but it is on the maximum of the curves rather than on the rise and therefore should be later. At Weber Lake a horizon of raised herb values was dated at $7300 \pm 140$ B.P. (U-163), and at Kirchner Marsh a decrease of Quercus and increase of upland herbs, along with evidence for a low lake level, were dated at $7120 \pm 110$ B.P. (Y-1140; Watts and Winter 1966). Also, the Ambrosia peak zone in the Quercus-Gramineae-Artemisia assemblage zone of McAndrews (1966) must be dated somewhere between 7000 and 8000 B.P.

All these changes, traceable over such a large area, must be the result of a major shift to a warmer, drier climate. It may serve as a second synchronous level in Minnesota pollen diagrams, the first being the pine rise at 10000 B.P. Simultaneously in northern and northeastern Minnesota Picea reaches its lowest percentages.

At Myrtle Lake the Pinus values at the top of the zone go down to less than $20 \%$, and it would be still lower when calculated on a pollen sum including Poaceae and Cyperaceae. This probably means, according to recent surface samples in areas west of the present coniferous region (McAndrews 1966), that Pinus was absent in the Myrtle Lake region, and that the pine pollen grains came from long-distance transport. The slight increase of Pinus strobus type may reflect its migration into easternmost Minnesota. 
The pollen assemblage resembles that of subrecent surface samples in Quercus savannas west of Lake Itasca (McAndrews 1966). Possibly local prairies were present, although, apart from Ambrosia, Artemisia, and Chenopodiaceae, the number of pollen grains from prairie species remains small. There is, however, a continuous curve for Iva ciliata type (cf. also Thompson Pond of McAndrews). The C-14 dates of the Quercus rise at bog D, Myrtle Lake, and Jacolson Lake suggest a migration from west to east. At bog $D$ the expansion of the prairie, the rise of Quercus, and the suppression of Picea started at $8560 \pm 120$ B.P. (Y-1419). At Myrtle Lake there is a rise of Quercus at $7850 \pm 120$ B.P. (Y-1780). This happens at Weber Lake at $7300 \pm$ 140 B.P. (U-163). At Jacobson Lake the date for the rise is not known but it is before $7210 \pm$ 80 B.P. (Y-1690). Clearly this migration is connected with the eastward penetration by the prairie in mid-postglacial time. At bog $\mathrm{D}$ and in the southern parts of Minnesota (KM and CBL) the rise of herbs and Quercus began well before 8000 B.P. This also resulted in an early total suppression of Picea. In northern and northeastern Minnesota the savanna arrived much later, and accordingly Picea reaches its lowest percentages at a later time in the postglacial. It seems thus that the distribution of Picea in this part of the postglacial is similar to that of Pinus, just as today. At Weber Lake in the far northeast of Minnesota there is only a slight rise of Quercus after a thin zone representing the dry interval of the prairie period. It seems that Quercus arrived there too late to profit from a climatic interval unfavorable for its competitors.

\section{Zone $M L-3 b$}

Zone $3 b$ is characterized by a decrease of upland herbs and an increase of mesic deciduous elements (Quercus, Ostrya type) and of Pinus strobus. In principle the pollen assemblage resembles those that postdate the prairie period at more southern (CBL) and western (BD) sites, where a Quercus-Ostrya assemblage zone follows a zone of Quercus and upland herbs. But because of the less strong impact of the dry interval in the north, this sort of assemblage zone follows immediately, at about 7000 B.P., whereas in the Lake Itasca area and at Cedar Bog Lake the transformation of the vegetation from savanna to deciduous forest came at about 4000 B.P.

In the lower half of the zone Pinus still shows low values, and the pollen assemblage much resembles that of recent samples in the deciduous forest west of Lake Itasca. The upland vegetation apparently was a deciduous type of forest, with Quercus, Ostrya, Tilia, Fraxinus pennsylvanica, and Ulmus. Ulmus pollen reaches a maximum a the base of the zone after minimal values in zone $3 a$.

But the Ulmus curve starts to decrease at the level (spectrum 48) where there is a sudden increase in the ratio of Pinus strobus type to Pinus banksiana/resinosa type. Although at this level the overall pine percentages seem a little low, it still might mean that at this time $P$. strobus migrated into the area. If so, then it seems likely that $P$. strobus began to replace Ulmus and slightly later also Ostrya and Fraxinus pennsylvanica, for it thrives on the same type of soils. The fate of the deciduous forest thus is clearly determined by the migration of Pinus strobus. At Weber Lake pine perhaps never was absent during the postglacial, and accordingly an Ostrya zone fails to show up. At Jacobson Lake Wright et al. (1968) emphasized a direct suppression of Quercus by Pinus strobus. At Myrtle Lake this is also true but mostly later in zone $3 b$. First there seems to be a replacement of Quercus by other hardwoods and by pine, a feature that is related to the general migration of pine towards the west at this time.

At the top of the zone Pinus strobus reaches such a high percentage $(60 \%)$ that it must have been present, although it may not have been very abundant.

The early arrival of pine in the northern and eastern parts of Minnesota thus suppresses the deciduous forest quite early. At Myrtle Lake the transition from zone $3 b$ to zone $3 c$, where Ostrya type is low again, is at $4840 \pm 120$ B.P. (Y-1779). At Jacobson Lake the date is not known, but the fall of Ostrya type is in zone JL-3 between $3920 \pm 120$ B P. (Y-1691) and $7210 \pm 80$ B.P. (Y-1690). In the Lake Itasca area the coniferous forest arrives much later (bog D: $2730 \pm 75$ B.P., Y-1156). It has been argued (Janssen 1967a) that the occurrence of Picea in lowlands depends on the type of upland forest. The same relationships exist at most of 
the other sites in the coniferous/hardwood formation: when pine arrives Picea also returns and thus appears earlier in the northeast than in the south.

\section{Zone $M L-3 c$}

In zone ML-3c there is a slight decrease of pine. In the curve based upon the regional pollen sum, most of the decline is a result of the increase of Betula, which might have been $B$. pumila, the bog birch. But if Betula is excluded, as for the upland pollen sum, there still remains a slight decrease of pine.

An increase of upland herbs (Ambrosia) is especially noticeable in the curve based upon the upland pollen sum. The pine ratio shifts slightly in favor of Pinus banksiana/resinosa type. There is no reaction whatsoever in the other tree types. Quercus and Ulmus continue their decline, and Ostrya type shows a final decrease. It is therefore not very probable that again the deciduous forests encroached upon pine. Perhaps forest fires swept through Pinus strobus stands, and semiprairies and Betula were involved in the regeneration stages. The increase of Pinus banksiana/resinosa type then would be a result of an intensified long-distance transport.

The Jacobson Lake diagram shows essentially the same relationships: a decrease of pine is largely at the expense of Betula, and at the same time there is a maximum of upland herbs, with a slight increase of Pinus banksiana/resinosa type. There is, however, a synchroneity problem. The base of zone 4 at Myrtle Lake is dated at $2680 \pm 120$ B.P. (Y-1778); at Jacobson Lake it is 3920 B.P., more than 1000 years earlier. Wright et al. (1968) stressed a climatic cause for the changes at the transition form zone 3 to zone 4 . And indeed, although in the north Picea, Larix, and Abies return earlier, the expansion of bogs occurred at Myrtle Lake and the Lake Itasca area at the same time, about 2800 B.P. If both phenomena have been triggered by a change to more humid conditions, then the Jacobson Lake date may be in error.

In zone ML-3c Acer saccharum reappears after having been absent for some time, a striking parallel with the succession of deciduous forest elements in the Lake Itasca area.

\section{Development of the Peatland in Zone ML-3}

In contrast to zone 2, the local pollen types in zone 3 clearly indicate the kind of peatland vegetation. In zone ML-3a there is a peak of Typha latifolia followed in zone $3 b$ by a maximum in Dryopteris type. Scattered throughout the zone are Lysimachia thyrsiflora, Campanula uliginosa type, Impatiens, Rumex orbiculatus type, Bidens type, and Cicuta type, indicating a rich fen. Insectiferous pollen grains like these usually do not occur in the regional pollen rain, unless the total pollen deposition is very low or unless these fen types covered unusually large areas. Most of the sedge peats at the base of the Myrtle Lake peatland must have originated during the time of zones $3 a$ and $3 b$.

In zone $3 c$ there is evidence for formation of swamp vegetation: Picea and Larix increase, and there are maxima of Alnus and Osmunda (a mesotrophic species of woods and thickets). Part of the Betula pollen grains, which show high numbers in this zone, may have come from Betula pumila, today typical of poor swamps, strings bogs, and fens. However, in these recent vegetation types Menyanthes trifoliata, Potentilla palustris, and Ericaceae occur. In the Myrtle Lake diagram, pollen grains of these plants do not occur until in the next zone. Therefore it seems likely that the swamp vegetation must have had a richer character than the present poor Larix swamps, fens, and string bogs.

The swamping of the sedge vegetation of the previous zone also is reflected in the diagram by a decrease of the Cyperaceae; and some of the rich fen species drop out.

Much of the forest peat that underlies Sphagnum sedge peat at the perimeter of the peatland (e.g. under the raised bog) may have originated during this time. If so, then paludification and expansion of the peatland had started. A C-14 date from amorphous peat underlying forest peat at the base of Lindford bog west of Myrtle Lake is $4360 \pm 160$ (W-562; Heinselman 1963), which is in agreement with this hypothesis.

But at the northern end of Myrtle Lake, forest peats overlie sedge peats almost up to the surface, so most of the pollen may have come from this area rather than from the periphery of the peatland. Today a conspicuous stand of Thuja occidentalis occurs at the northern end of the lake. In zone 3 Thuja is not absent, but its percentages remain low and its curve is discontinuous. 
Myrica shows three peaks in this zone. In continental regions in northern America Myrica is not a true bog species, but it occurs in swamps (Heinselman 1968; Gates 1942) and on mineral soils along shores of lakes and rivers. In fact even today there is a belt of Myrica along the two stream remnants at the southern end of the lake (Fig. 3A). Myrica may have occurred all around the lake. Also during zone 3 time, before the paludification of large areas, greater exposure of beaches may account for the prominence of Myrica in the pollen diagram. Another possibility is dust storms, which may have favored Myrica in peatland areas.

The pollen zonation is reflected in the behavior of the alga Pediastrum. Pediastrum duplex $\mathrm{f}$. cohaerens is almost restricted to zones $3 a$ and $3 b$, whereas other Pediastrum duplex varieties, Pediastrum boryanum var. longicorne, and Pediastrum integrum are most abundant in zone $3 c$. Pediastrum boryanum, after three striking maxima, decreases strongly halfway through zone $3 c$. The ecological significance of these phenomena is not known, but they are clearly related to changes in the vegetation of the peatlands.

\section{ZONE ML-4}

\section{Regional Features}

At the base of the zone Pinus strobus type increases and stays at a relatively high percentage level. The species had migrated much earlier into the area and had remained a minor component in the vegetation, but then, perhaps a result of the climatic change postulated by Wright, it became important. Also, Abies reaches maximal values. In contrast, the percentages of the deciduous trees and upland herbs are at their lowest level in the diagram.

The curves of Pinus and Abies faintly mirror each other in detail, reflecting perhaps fires in Pinus stands, after which Abies (and Betula) come in. According to Heinselman (conversation), a succession from Pinus to Abies happened not long ago on a rock island in the Myrtle Lake peatland. In the upper part of the zone there are occurrences of Tsuga, reflecting the increase of Tsuga canadensis east of Minnesota in Wisconsin. Also, one grain of Fagus was found in this zone.

At the top of the zone Ambrosia, Chenopodia- ceae, and Poaceae rise as a result of the arrival of the white man. This is the third synchronous level in Minnesota diagram.

There is a decrease of pine in the topmost sample of the core, perhaps the effect of lumbering in the area, which was relatively late in this part of the state.

\section{Development of the Myrtle Lake Peatland at the Time of Zone ML-4}

In zone 4 Sphagnum and Ericaceae appear, indicating that the formation of Sphagnum peat began, leading to the present raised bog in the Myrtle Lake peatland and also leading perhaps to the formation of poor swamps and fens. There is a strong rise of Picea, Thuja, and Osmunda. The rise of Picea is clearly a result of the increase of suitable habitats. It occurs not only on the raised bog in the northern part of the peatland and on the spruce islands in the area and around the lake, but lateral expansion of the entire peatland (Heinselman 1963) provided potential new areas for colonization at the margin. Thuja also profited from the availability of suitable areas along the margin of the peatland, but its rise in this zone might have been a result of an increase of Thuja at the northern end of the lake. The same may apply to Osmunda. Larix shows only a slight rise. At the margin of the peatland new areas became available, but at the same time the rich swamp vegetation from zone 3 became impoverished. At the top of the zone Larix decreases, perhaps a result of continued impoverishment and the formation of raised bogs.

There is a continuous decrease of pollen types characteristic for minerotrophic fens. Alnus, Salix, Fraxinus nigra, and Dryopteris type decline to low percentage levels. Pollen from minerotrophic herbs occurs mainly in the lower part of the zone. The regional events are accompanied by a striking change in the species of Pediastrum in Myrtle Lake. At the transition from zones 3 to 4, Pediastrum boryanum ceases to occur, and from then on Pediastrum is rare in the lake sediments except for Pediastrum integrum, which decreases but still remains present. According to Schroevers (conversation) Pediastrum is a genus that generally is absent from raised bogs, but, if present, then Pediastrum integrum is the most likely species. On the other 
hand, the surprisingly high $\mathrm{pH}$ of the lake today (Heinselman 1968) should not prevent Pediastrum from occurring.

\section{Concluding Remarks}

Several sites across Minnesota (bog D, Jacobson Lake, Stevens Pond, Cedar Bog Lake, Weber Lake) show that bog vegetation entered the area during the mid-postglacial time of eastward prairie expansion. Pinus, Picea, and Larix increased at the same time. At the start of the prairie period, Picea and Larix had disappeared or greatly decreased, as a deciduous type of forest or savanna replaced the conifer/hardwood forests of zone 2, first in the south and west and later in the north. One may visualize relics of the original spruce forest of the late-glacial during the subsequent pine period in favorable sites (bogs), where pine and hardwoods cannot compete with spruce. ${ }^{2}$ Finally, these last remnants in lowland areas were destroyed when pine disappeared from the uplands. Spruce returned with the reintroduction of pine in the late postglacial.

In an earlier paper (Janssen 1967a), the relation between the lowland succession and that of the upland was stressed. In the case of a small basin (Stevens Pond), this relationship is most easily explained by differences in the chemical composition of the runoff water from different types of upland forests. For a vast area like the Myrtle Lake Peatland, such a relationship seems less probable, and here perhaps there is a more direct influence of climate on the peatland vegetation by a change in the proportion of precipitation to evaporation. For most of its development, however, the overall character was that of a soligeneous peatland, and the expansion of the pines in zone 4 on the uplands may have changed the chemical composition of the inflow into the area.

The available radiocarbon dates suggest that raised bogs started to form about 3000 years ago, perhaps initiated by a worldwide change in climate (end of the Hypsithermal: Deevey and Flint 1957). Of course, upland trees are also

${ }^{2}$ In older diagrams from Indiana (Griffin 1950), Michigan (Potzger 1948), and Maine (Potzger and Friesner 1948), where a distinction between Picea mariana and $P$. glauca pollen was made on the basis of size, $P$. mariana stays on longer than $P$. glauca during the lower pine period, perhaps in bogs. influenced by climate, although to a smaller degree. There is therefore a possibility that the arrival of pine in the Lake Itasca area was a result of the same climatic event that caused a pine expansion in the Myrtle Lake area and the start of bog expansion. If the C-14 date for the transition from zone 3 to zone 4 at Jacobson Lake is correct, this would mean that bog expansion started earlier here than in regions more towards the west. Another possibility has been pointed out by Heinselman (1968), who considered that increased erosion and drainage to the east was responsible for an intensified outflow of nutrients. If this is so, then the start of the bog expansion is a local feature and most likely would not be synchronous with the start of bogs in other regions. To solve these problems more analyses from peat cores and C-14 dates across the state are needed.

\section{Acknowledgments}

The investigation was supported by grants to the University of Minnesota by the National Science Foundation (Grant GB-3814) and the Hill Family Foundation (St. Paul). Among the many people that were involved were Dr. H. E. Wright, who provided the spark that ignited my interest in bog ecology, and Dr. M. L. Heinselman, who introduced me to the Myrtle Lake peatland and with whom I had some interesting excursions across the bog. Dr. P. J. Schroevers kindly provided data on the ecology of Pediastrum. Dr. E. J. Cushing criticized the manuscript. The radiocarbon dates were kindly furnished by Dr. Minze Stuiver of the Yale University Radiocarbon Laboratory.

Cusinng, E. J. 1963. Lake-Wisconsin pollen stratigraphy in east-central Minnesota. Univ. Minnesota Ph.D. Thesis.

1964. Redeposited pollen in late-Wisconsin pollen spectra from east-central Minnesota. Am. J. Sci. 262: 1075-1088.

1967. Late-Wisconsin pollen stratigraphy and the glacial sequence in Minnesota. In Quaternary paleoecology. Edited by E. J. Cushing and H. E. Wright, Jr. Yale Univ. Press. pp. 59-88.

Cushing, E. J. and Wright, H. E., JR. 1965. Handoperated piston corer for lake sediments. Ecology, 46: 380-384.

Deevey, E. S. and Funt, R. F. 1957. Postglacial hypsithermal interval. Science, 125: 182-184.

FAEGRI, K. and IVERSEN, J. 1964. Textbook of pollen analysis. Copenhagen, Munksgaard.

FRIES, M. 1962. Pollen profiles of late Pleistocene and Recent sediments from Weber Lake, Minnesota. Ecology, 43: 295-308. 
Gates, F. C. 1942. The bogs of northem lower Michigan. Ecol. Monographs, 12:214-254.

GriffiN, C. D. 1950. A pollen profile from Reed Bog, Randolph County, Indiana. Butler Univ. Botan. Studies, 9: 131-139.

Heinselman, M. L. 1963. Forest sites, bog processes, and peatland types in the Glacial Lake Agassiz region, Minnesota. Ecol. Monographs, 33: 327-374.

1968. Landscape evolution, peatland types, and the environment in the Lake Agassiz peatlands natural area, Minnesota. Unpublished manuscript.

IVERSEN, J. 1954. The late-glacial flora of Denmark and its relation to climate and soil. Danmarks Geol. Undersøgelse II, 80: 87-119.

JANSSEN, C. R. 1966. Recent pollen spectra from the deciduous and coniferous-deciduous forests of northeastern Minnesota: a study in pollen dispersal. Ecology, 47: 804-825.

- 1967a. Stevens Pond: a postglacial pollen diagram from a small Typha swamp in northwestern Minnesota, interpreted from pollen indicators and surface samples. Ecol. Monographs, 37: 145-172.

$1967 b$. A floristic study of forests and bog vegetation, northwestern Minnesota. Ecology, 48: 751-765.

LEVERETT, F. 1915. Surface formations and agricultural conditions of northwestern Minnesota. Minn. Geol. Surv. Bull. 12.

1932. Quaternary geology of Minnesota and parts of adjacent states. U.S. Geol. Surv. Prof. Paper, 161.

Löve, D. 1959. The postglacial development of the flora of Manitoba: a discussion. Can. J. Botany, 37: 547585.

McANDrews, J. H. 1966. Postglacial history of prairie, savanna, and forest in northwestern Minnesota. Mem. Torrey Botan. Club, 22 (2).

Potzger, J. E. 1948. A pollen study in the tension zone of lower Michigan. Butler Univ. Botan. Studies, 8: 161-177.

Potzger, J. E. and Friesner, R. C. 1948. Forests of the past along the coast of southern Maine. Butler Univ. Botan. Studies, 8: 178-190.
PrescotT, G. W. 1951. Algae of the western Great Lakes area. Cranbrook Inst. Science., Bloomfield Hills, Mich.

RaUP, H. M. 1935. Botanical investigations in Wood Buffalo Park. Natl. Museum Can. Bull. 74.

RrTcHIE, J. C. 1957. The vegetation of northern Manitoba. II. A prisere on the Hudson Bay lowlands. Ecology, 38: 409-435.

SChoENIKE, R. F. 1962. The distribution of Jack pine in Minnesota. Univ. Minnesota Agr. Expt. Sta. Sci. J. Ser. Paper 4762.

Shay, C. T. 1965. Postglacial vegetational development in northwestern Minnesota and its implications for prehistoric human ecology. Univ. Minnesota, M.S. Thesis.

Thieret, J. W. 1964. Botanical survey along the Yellowknife Highway, Northwest Territories, Canada. So. Methodist Univ., Sida, Contr. Botany, 1: 184-256.

WATTS, W. A. 1967. Late-glacial plant macrofossils from Minnesota. In Quaternary paleoecology. Edited by E. J. Cushing and H. E. Wright, Jr. Yale Univ. Press. pp. 89-97.

WatTs, W. A. and Winter, T. C. 1966. Plant macrofossils from Kirchner Marsh, Minnesota: a paleoecological study. Geol. Soc. Am. Bull. 77: 1339-1360.

WrIGHT, H. E., JR. 1964. Aspects of the early postglacial forest succession in the Great Lakes region. Ecology, 45: $439-448$.

WRIGHT, H. E., JR. and RUHE, R. V. 1965. Glaciation of Minnesota and Iowa. In The Quaternary of the United States. Edited by H. E. Wright, Jr, and D. G. Frey. Princeton Univ. Press. pp. 29-41.

Wright, H. E., JR., Winter, T. C., and Patten, H. L. 1963. Two pollen diagrams from southeastern Minnesota: problems in the regional late-glacial and postglacial vegetational history. Geol. Soc. Am. Bull. 74: 1371-1396.

Wright, H. E., JR., WAtts, W. A., and Jelgersma, S. 1968. Glacial and vegetational history of northeastern Minnesota. Unpublished manuscript.

ZolTAI, S. 1961. Glacial history of part of northwestern Ontario. Geol. Assoc. Can. Proc. 13: 61-83.

Note: Table II and Fig. 4 follow. 